\title{
GAIN AND MAXIMUM OUTPUT OF IMPLANTABLE HEARING DEVICES IN PATIENTS WITH MODERATE TO SEVERE SENSORINEURAL HEARING LOSS
}

\author{
Joost W. Zwartenkot ${ }^{1,2}$, Ad F. M. Snik ${ }^{1,2}$, Martin Kompis ${ }^{3}$, Christof Stieger ${ }^{3,4}$ \\ ${ }^{1}$ Department of Otorhinolaryngology \& Head and Neck Surgery, Radboud University Nijmegen Medical Centre, \\ Nijmegen, The Netherlands \\ ${ }^{2}$ Centre for Neuroscience, Donders Institute for Brain, Cognition and Behaviour, Nijmegen, The Netherlands \\ ${ }^{3}$ Department of ENT, Head and Neck Surgery, Inselspital, University of Bern, Bern, Switzerland \\ ${ }^{4}$ ARTORG Center for biomedical engineering research, University of Bern, Bern, Switzerland
}

Financial disclosure: none.

Conflict of interest: none.

Corresponding author: Joost W. Zwartenkot, Department of Otorhinolaryngology, Head and Neck Surgery, Radboud University Nijmegen Medical Center, P.O. Box 9101, 6500 HB Nijmegen, The Netherlands, e-mail: j.zwartenkot@kno.umcn.nl

\begin{abstract}
Background: To determine the dynamic range and the maximum output of three current middle ear implants and to discuss optimal candidacy for middle ear implantation.

Study Design: Clinical study.

Material and Methods: Gain and output measurements were compared for three types of middle ear implants: the Otologics middle ear transducer (MET), the Vibrant Soundbridge (VSB), and the Direct Acoustic Cochlear Stimulator (DACS). The performance of these selected implants in users with severe, predominantly sensorineural, hearing loss (50-65 dB HL) was studied. Patients with chronic external otitis and sensorineural hearing loss used either a MET $(n=9)$ or a VSB $(n=9)$ implant. Patients with a predominantly sensorineural hearing loss after surgically treated otosclerosis used a DACS $(n=4)$. Patients were selected from two different implant teams but evaluated with the same protocol. The relative gain at threshold level was determined, viz. the bone-conduction threshold minus the aided soundfield threshold, divided by the bone-conduction threshold. Input-output measurements were performed with the devices in linear amplification mode and with unlimited output. In this latter data set, the maximum output and the input dynamic range of the devices were determined.
\end{abstract}

Results: The relative gain for each of the three implants was comparable; however, the values were slightly lower than the generally accepted target values. The input dynamic range of the devices varied, with the widest range for the DACS and Otologics devices.

Conclusion: The results from this study indicate that the first generation DACS device is a good option for patients with moderate/severe sensorineural hearing loss and surgically treated otosclerosis who require a hearing implant.

Key words: middle ear implants • implantable hearing aids • otologics MET • Vibrant Soundbridge $\bullet$ VSB $\bullet$ DACS • dynamic range

\section{MEJORA Y SALIDA MÁXIMA DE DISPOSITIVOS AUDITIVOS IMPLANTABLES EN PACIENTES CON MODERADA A SEVERA PÉRDIDA AUDITIVA NEUROSENSORIAL}

\section{Extracto}

Antecedentes: Determinar el rango dinámico y la salida máxima de tres implantes actuales del oído medio y analizar la candidatura óptima para la implantación del oído medio.

Diseño del Estudio: Estudio clínico.

Material y Métodos: Se compararon las mediciones de beneficio y salida de tres tipos de implantes del oído medio: el transductor de oído medio de Otologics (MET), Vibrant Soundbridge (VSB), y el Estimulador Directo Acústico de Cóclea (DACS). Se estudió la salida de estos implantes seleccionados en usuarios con grave pérdida de la audición, predominantemente neurosensorial 
(50-65 dB HL). Los pacientes con otitis externa crónica y pérdida de audición neurosensorial utilizaron el implante MET ( $\mathrm{n}=9$ ) o VSB ( $n=9)$. Los pacientes con una pérdida auditiva predominantemente neurosensorial después del tratamiento quirúrgico de otosclerosis utilizaron DACS $(\mathrm{n}=4)$. Los pacientes fueron seleccionados de dos equipos diferentes de implantes pero fueron evaluados utilizando el mismo protocolo. Se determinó la mejora relativa en el nivel umbral, a saber, el umbral de conducción ósea menos el umbral de campo de sonido asistido, dividido por el umbral de conducción ósea. Las mediciones de entradasalida se realizaron con los dispositivos en modo de amplificación lineal y con la salida ilimitada. En este último conjunto de datos, se determinó la salida máxima y el rango dinámico de entrada de los dispositivos.

Resultados: El beneficio relativo para cada uno de los tres implantes fue comparable, sin embargo, los resultados fueron ligeramente inferiores que los valores objetivo generalmente aceptados. El rango dinámico de entrada de los dispositivos varió, el rango más amplio siendo él de dispositivos DACS y Otologics.

Conclusión: Los resultados de este estudio indican que la primera generación del dispositivo DACS es una buena opción para los pacientes con moderada / severa pérdida auditiva neurosensorial y otosclerosis tratada quirúrgicamente que requieren un implante auditivo.

Palabras claves: implantes de oído medio • audífonos implantables • otologics MET • Vibrant Soundbridge • VSB • DACS • rango dinámico

\section{УСИЛЕНИЕ И МАКСИМАЛЬНАЯ МОЩНОСТЬ ВЖИВЛЯЕМЫХ СЛУХОВЫХ УСТРОЙСТВ У ПАЦИЕНТОВ С УМЕРЕННОЙ И ТЯЖЕЛОЙ СЕНСОНЕЙРОННОЙ ПОТЕРЕЙ СЛУХА}

\section{Резюме}

Предпосылки: Определить динамический диапазон и максимальную мощность трех современных имплантов среднего уха и обсудить оптимальных кандидатов на импланты среднего уха.

Испытания: Клинические испытания.

Материалы и Методы: Сопоставленны измерения усиления и мощности трех типов имплантов среднего уха: отологический трансдьюсер среднего уха (MET), имплант Vibrant Soundbridge (VSB) и непосредственный акустический кохлеарный стимулятор (DACS). Мы исследовали дейтвие этих выбраных имплантов главным образом у пользователей с тяжелой сенсонейронной потерей слуха (50-65 дБ HL). Пациенты с хроническим наружным отитом и сенсонейронной потерей слуха пользовались имплантом MET (n=9) либо VSB (n=9). Пациенты в основном с сенсонейронной потерей слуха после леченного операционным путем отосклероза пользовались имплантом DACS $(\mathrm{n}=4)$. Пациенты были выбраны из двух разных имплантных команд, но они оценивались по тому самому протоколу. Определено соответственное усиление порогового уровня, а именно порог костной проводимости минус порог звукового поля со вспомоганием разделенный порогом костной проводимости. Входные- выходные измерения произведены с помощью устройств в линейном усиленном режиме и с неограниченной мощностью. В этом последнем составе данных определена максимальная мощность и динамический входной диапазон устройств.

Результаты: Соответсвенная мощность каждого из трех имплантов - сравнимая; однако, значения были немного ниже, чем общепринятые заданные значения. Динамический входной диапазон устройств изменялся, при чем самый широкий диапазон имели импланты DACS и Otologics.

Заключение: Итоги этих исследований показывают, что аппарат первой генерации DACS - это хорошая возможность для пациентов с умеренной/тяжелой сенсонейронной потерей слуха и леченным хирургическим путем отосклерозом, которые требуют слухового импланта.

Ключевые слова: импланты среднего уха • вживляемые слуховые аппараты • Otologics MET • Vibrant Soundbridge • VSB • DACS • динамический диапазон

\section{Background}

Several types of implantable hearing systems, or active middle ear implants (AMEI), have been introduced over the last two decades. In 1996, the Vibrant Soundbridge (VSB, Med-El, Innsbruck, Austria) became available for clinical evaluation [1], and this was followed by the Otologics Middle Ear Transducer (MET, Otologics LLC, Boulder, CO, USA). These semi-implantable devices have been successfully applied in patients with sensorineural hearing loss [2-4]. These devices typically consist of an actuator directly coupled to the ossicular chain and driven 


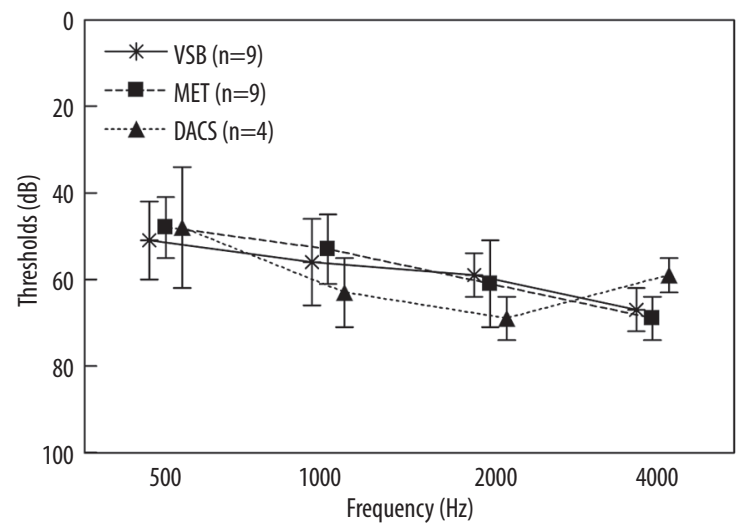

Figure 1. Mean bone-conduction thresholds plotted as a function of frequency for three groups of middle ear implant users: patients using the Vibrant Soundbridge (VSB), the Otologics MET (MET), and the DACS. Vertical bars are standard deviations.

by an external audio processor [5]. More recently, middle ear implants have also been used in patients with otosclerosis [6-9].

The Direct Acoustic Cochlear Stimulator (DACS) device, introduced in 2006, is a version of a semi-implantable middle ear implant that bypasses the outer and middle ear structures and directly stimulates the cochlea $[10,11]$. The DACS has been used in a feasibility study of patients with moderate/severe sensorineural hearing loss due to otosclerosis.

The DACS system is an actively-driven stapes prosthesis; an electromagnetic actuator is implanted in the mastoid cavity and connected to a conventional stapes prosthesis, which directly drives inner ear fluid movement. The external audio processor is connected to the actuator by a percutaneous plug. In the first DACS study, the ossicular chain was reconstructed during the implantation surgery by inserting an additional, passive stapes prosthesis [11]. This surgery reduced the air-bone gap and postoperatively left a predominantly sensorineural hearing loss for the patients.

Traditionally, to measure the gain and output of conventional hearing devices, artificial simulators are used. For middle ear implants, such simulators are not available; therefore, the basic amplification characteristics are typically measured in patients. For example, to measure gain, the functional gain (FG) can be determined by subtracting the aided sound field thresholds from the unaided sound field thresholds. However, measuring FG can be problematic when used on middle ear implant devices for three reasons. First, if an air-bone gap is present after surgery, this will raise the unaided threshold proportionally and will overestimate the FG. The measured FG will then be the sum of the pure device gain plus the postsurgery air-bone gap. Second, noise-reduction algorithms, which are often present in current hearing devices including middle ear implants, can interpret test signals as noise and consequently reduce amplification. Finally, the middle ear implants studied here make use of adaptive, non-linear amplification. Therefore, sound field threshold measurements evaluate the (relatively high) gain for soft sounds and overestimate the gain for conversational speech levels [12].

An additional amplification characteristic is the saturation (SAT) level of the device, which is the loudest input sound that can be properly processed by the device. The input level at the point of saturation can be measured by studying the output behavior of the device. Previous research has shown that it is possible to measure output limitations objectively with a microphone placed in the ear canal. In the current study, we have compared the basic capacities of three implantable hearing systems. The gain of the devices was compared in matched patient groups. In addition, the dynamic range and maximum output of the three devices were determined while the devices were in linear amplification mode with unlimited output. The results of this study are used to discuss optimal candidacy for middle ear implants.

\section{Material and Methods}

\section{Patients}

All data were acquired from patients who used a (unilateral) middle ear implant: four DACS users (the only patients with the first generation DACS as described by Hausler et al. [11]); nine VSB users selected from the Nijmegen database of 55 VSB users; and nine MET users, selected from the same database of 18 MET users. VSB and MET users were matched with the DACS users based on the degree of preoperative sensorineural hearing loss (criteria: boneconduction thresholds between 30 and $60 \mathrm{~dB} \mathrm{HL}$ at 500 $\mathrm{Hz}$ and between 50 and $75 \mathrm{~dB} \mathrm{HL}$ at $4 \mathrm{kHz}$ and a mean hearing loss of between 50 and $65 \mathrm{~dB} \mathrm{HL}$ at $0.5,1,2$, and $4 \mathrm{kHz}$ ) and the length of device use (minimum of 1 year).

Figure 1 shows the mean preoperative bone-conduction thresholds of the implanted ear in patients from each group. The VSB and MET users had been provided with implants due to therapy-resistant chronic external otitis. These patients had a predominantly sensorineural hearing loss, although an air-bone gap in the order of 5-10 dB was common. Prior to treatment, the DACS patients showed both sensorineural and conductive hearing loss caused by otosclerosis. At the DACS post-operative evaluation, the air-bone gap had been reduced because the fixed stapes had been replaced by a secondary, passive stapes prosthesis [11]. A mean air-bone gap of $14 \mathrm{~dB}$ remained at $0.5,1$, 2 , and $4 \mathrm{kHz}$ (range 6-20 dB).

The VSB users were fitted with the 404 audio processor (Med-El, Innsbruck, Austria); the MET users were fitted with the Button processor (Otologics LLC, Boulder, CO, USA); and the DACS users were fitted with the Savia 211 processor (Phonak, Staefa, Switzerland). All fittings were done by experienced audiologists.

\section{Parameters}

The two parameters used in this study are an FG-based gain ratio (GR) and the input level at output saturation (ILS) [13]. 


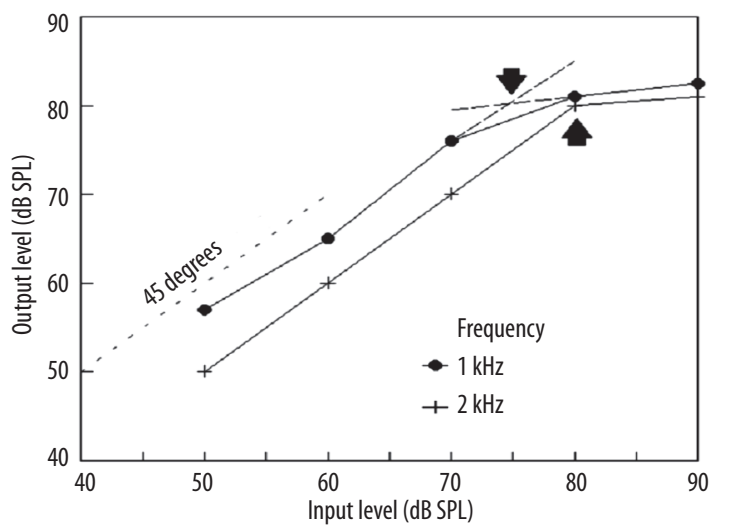

Figure 2. Input-output curves at $1 \mathrm{kHz}$ and $2 \mathrm{kHz}$ obtained from probe-tube microphone measurements in the ear canal of a patient with a DACS device. The arrows indicate the level of device saturation.

\section{Gain ratio $(\mathrm{GR})$}

The bone conduction, based on the functional gain at the threshold level, was defined as the difference between the bone-conduction threshold and the aided threshold. This value, divided by the bone-conduction threshold, was called the gain ratio (GR) and was calculated for each frequency. The GR at each frequency can be compared with target values, as produced by prescription rules. According to the commonly used NAL-NL prescription rule, for conversational levels, the GR should be 0.46 ; this indicates that the desired FG should be approximately 0.46 times the hearing threshold (at 1-4 kHz) [14]. For softer sounds, ratios higher than 0.46 are prescribed [15]. These reference ratios can be used to assess the adequacy of amplification provided by the middle ear implant. This ratio is independent of the patient's degree of hearing loss, unlike the FG. To determine the GR, noise-reduction algorithms were deactivated. All other settings were the patient's daily settings.

\section{Input level at output saturation (ILS)}

To determine the input level at saturation for the three implant devices, the procedure described by Snik et al. was followed [13]. Briefly, sound pressure levels were measured with the Aurical REM system in the ear canal of the aided ear (Madsen, Taastrup, Denmark). Measurements were conducted while the ear canal was occluded with an EARlink foam tip (Aearo Company, Indianapolis, IN, USA). After a foam tip was inserted, a probe tube microphone was pushed through the standard opening in the plug. In this manner, the sound pressure level could be measured in the occluded ear canal. Sound pressure levels were recorded as a function of frequency during the presentation of a calibrated frequency sweep produced in the sound field (sweep from $250 \mathrm{~Hz}$ to $8 \mathrm{kHz}$ at $60 \mathrm{~dB} \mathrm{SPL}$, as standard on the Aurical REM system). The first measurement was carried out with the audio processor off (reference curve), and the measurement was repeated with the audio processor on. The difference curve was used for further analysis. Similar curves were obtained at 50, 70, 80, and $90 \mathrm{~dB}$ SPL. From the difference curves, the input level at which the device saturated was determined at $1 \mathrm{kHz}$ and $2 \mathrm{kHz}$. Figure

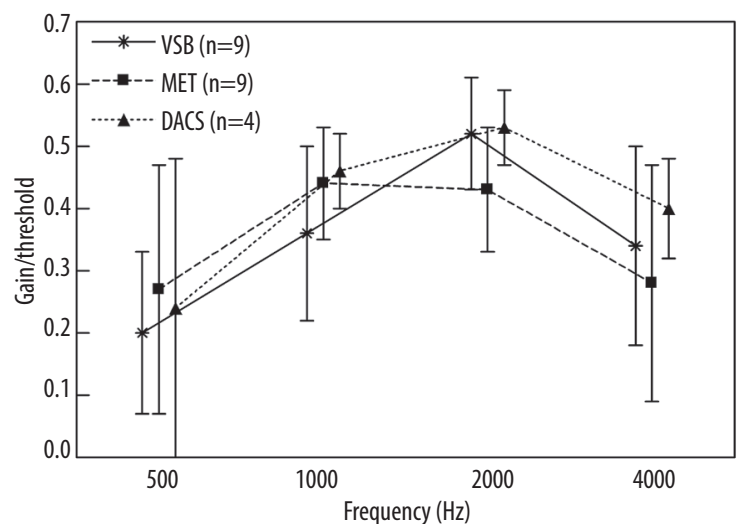

Figure 3. Functional gain at threshold level divided by bone-conduction threshold versus frequency for three groups of middle ear implant users: patients using the Vibrant Soundbridge (VSB), the Otologics MET (MET), and the DACS. Mean values are displayed with standard deviations.

2 shows representative data. Output limiting options were deactivated, and the device was programmed in the linear amplification mode.

To measure sound field thresholds, warble tones were presented via a loudspeaker placed $1 \mathrm{~m}$ in front of the patient and calibrated according to Morgan et al. [16].

Nine of the 22 patients participated in a special session to measure the output limitation of the devices (three MET users, four VSB users, and two DACS users). These patients were randomly selected. The measurements were carried out in sound-proof double-walled rooms.

\section{Results}

The GR as a function of frequency is presented in Figure 3. The mean data are presented separately for the matched VSB, MET, and DACS users. Vertical lines indicate standard deviations.

A representative example of an input-output measurement, as derived from sound-pressure measurements in the occluded ear canal, is presented in Figure 2. After turning the device on, there was an increase of $15-20 \mathrm{~dB}$ SPL at 1 to $3 \mathrm{kHz}$ in the ear canal. The data in Figure 2 are from a patient using a DACS device. These data have a linear increase until the output levels-off at an input level of $75 \mathrm{~dB}$ SPL at $1 \mathrm{kHz}$ and 80 $\mathrm{dB}$ SPL at $2 \mathrm{kHz}$. In a second patient with a DACS, the input level at saturation was above $80 \mathrm{~dB}$ SPL; this patient could not tolerate stimulation louder than $80 \mathrm{~dB}$ SPL. For the other two implant systems, the output saturated at lower input levels. Figure 4 shows the maximum dynamic range of the three devices, which is defined as the difference between the input level at saturation and the aided thresholds, expressed in $\mathrm{dB}$ SPL, and obtained in the linear amplification mode.

\section{Discussion}

In contrast to studies that assess individual benefit and satisfaction levels, the measurements in the current study 


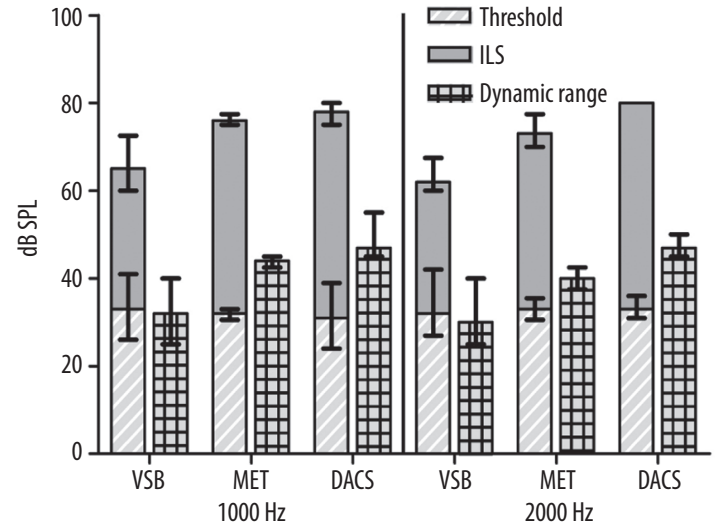

Figure 4. Hearing thresholds (stripes), input level at saturation (grey), and dynamic range (cross-hatch) for the three groups of patients as measured at $1 \mathrm{kHz}$ (left columns) and $2 \mathrm{kHz}$ (right columns). Mean data with ranges are presented. The audio processors were programmed in linear amplification mode and the maximum output was not limited.

are device-specific, not patient-specific dynamic range and maximum output, and are therefore helpful when comparing systems. While previous studies addressed benefit measures, such as speech perception and patient opinions, this study investigated the basic performance of three active, semi-implantable middle ear devices used in patients matched according to the extent of their sensorineural hearing loss. Previously, it has been shown that the gain (amplification) and maximum output are important parameters in evaluating the basic operation of implantable hearing systems $[13,17]$.

Figure 3 shows the gain ratio (GR), a measure that is, in principle, hearing-loss independent and can therefore be averaged over patients. Significant differences between the three devices were not found ( $t$-test, $p>0.05$ ). This result is not surprising because the actual gain is determined by the user, either by adjusting the volume (MET and DACS), or, if volume control is absent, by adjustments made during the device fitting. The desired gain ratio, according to the NAL rule, should be at least 0.46 (at 1,2 , and $4 \mathrm{kHz}$ ). This GR was found at $1 \mathrm{kHz}$ and $2 \mathrm{kHz}$ for the DACS users and at $2 \mathrm{kHz}$ for the VSB users; for MET users, the values at $1 \mathrm{kHz}$ and $2 \mathrm{kHz}$ approached this target value. A target ratio of 0.46 , as prescribed by the NAL rule, was matched but not surpassed by the three systems $[14,15]$.

As shown by Snik et al., the proper processing of loud sounds by the implant can be measured objectively with a probe microphone in the ear canal [13]. The probe measures the vibrations produced by the actuator of the middle ear implant because these reach not only the cochlea but also the tympanic membrane. The probe thus measures the vibrations produced as a by-product. Although such measurements cannot be used to assess gain, they can be used to study the input-output behavior of middle ear implants [13]. Measuring input-output behavior was possible with the VSB, the MET, and the DACS (Figure 2). The input level at saturation was higher for the DACS than for the MET or VSB. As a consequence, the dynamic range was the widest for the DACS (see Figure 4). These data can, in part, be attributed to the percutaneous coupling between the actuator and audio processor, which may be more effective than the contactfree, radio-frequency coupling in the VSB and MET [18].

The individual (dynamic) hearing range of a patient can be determined from audiograms as the difference between the hearing thresholds and the loudness discomfort levels, or UCL [14]. For patients with a sensorineural hearing loss of 50-65 dB HL, the dynamic hearing range is in the order of 50-60 dB [19]. The DACS device best approaches this value (Figure 4). When the dynamic range of a hearing device is less than the patient's hearing range, patients may choose to lower the gain to widen the dynamic range and prevent the distortion of loud sounds, such as from their own voice, due to device saturation. This may explain why the amplification results for the VSB and MET are slightly, although not significantly, lower than those for the DACS (Figure 3).

Figure 4 shows that, for each device type, particularly for the VSB versus the DACS, the range of input level at saturation minimally overlapped, suggesting that differences between the devices are important.

A limitation of the present study is the small number of patients in the maximum output measurements. However, in the present protocol these measurements are not patient-specific, but device-specific, so subjective patient factors are avoided.

Compared to the implantation of the VSB and the MET, the DACS surgery is more invasive because the vestibulum is entered and this can lead to damage. The risk of cochlear damage in the DACS surgical procedure is thought to be comparable to that of a classical stapedotomy because a standard stapes prosthesis is used [11]. Furthermore, the DACS system was designed to be used only in patients with mixed hearing loss caused by otosclerosis.

\section{Conclusion}

The results of the present study suggest that the percutaneous DACS middle ear implant has a amplification capacity that exceeds the VSB and has a comparable or better capacity than the Otologics MET middle ear implant; because of this larger dynamic range it can therefore be of assistance in patients with moderate to severe sensorineural hearing loss.

\section{References:}

1. Dietz TG, Ball GR, Katz BH: Partial implantable vibrating ossicular prosthesis IEEE Electron Device Society. Chicago, 1997: 433-36
2. Labassi S, Beliaeff M: Retrospective of 1000 patients implanted with a vibrant Soundbridge middle-ear implant. Cochlear Implants Int, 2005; 6(Suppl.1): 74-77 
3. Verhaegen VJ, Mylanus EA, Cremers CW, Snik AF: Audiological application criteria for implantable hearing aid devices: a clinical experience at the Nijmegen ORL clinic. Laryngoscope, 2008; 118: 1645-49

4. Jenkins HA, Niparko JK, Slattery WH et al: Otologics Middle Ear Transducer Ossicular Stimulator: performance results with varying degrees of sensorineural hearing loss. Acta Otolaryngol, 2004; 124: 391-94

5. Kasic JF, Fredrickson JM: The Otologics MET ossicular stimulator. Otolaryngol.Clin.North Am, 2001; 34: 501-13

6. Venail F, Lavieille JP, Meller R et al: New perspectives for middle ear implants: first results in otosclerosis with mixed hearing loss. Laryngoscope, 2007; 117: 552-55

7. Beltrame AM, Martini A, Prosser S et al: Coupling the Vibrant Soundbridge to cochlea round window: auditory results in patients with mixed hearing loss. Otol Neurotol, 2009; 30: 194-201

8. Dumon T, Gratacap B, Firmin F et al: Vibrant Soundbridge middle ear implant in mixed hearing loss. Indications, techniques, results. Rev Laryngol Otol Rhinol (Bord), 2009; 130: $75-81$

9. Kontorinis G, Lenarz T, Mojallal H et al: Power stapes: an alternative method for treating hearing loss in osteogenesis imperfecta? Otol Neurotol, 2011; 32: 589-95

10. Bernhard H, Stieger C, Perriard Y: New implantable hearing device based on a micro-actuator that is directly coupled to the inner ear fluid. Conf Proc IEEE Eng Med Biol Soc, 2006; 1: 3162-65
11. Hausler R, Stieger C, Bernhard H, Kompis M: A novel implantable hearing system with direct acoustic cochlear stimulation. Audiol Neurootol, 2008; 13: 247-56

12. Snik AF, Cremers CW: Vibrant semi-implantable hearing device with digital sound processing: effective gain and speech perception. Arch Otolaryngol Head Neck Surg, 2001; 127: 1433-37

13. Snik AF, Noten J, Cremers C: Gain and maximum output of two electromagnetic middle ear implants: are real ear measurements helpful? J Am Acad Audiol, 2004; 15: 249-57

14. Dillon H: Hearing Aids. New York: Thieme Verlag, 2001

15. Byrne D, Dillon H, Ching T et al: NAL-NL1 procedure for fitting nonlinear hearing aids: characteristics and comparisons with other procedures. J Am Acad Audiol, 2001; 12: 37-51

16. Morgan DE, Dirks DD, Bower DR: Suggested threshold sound pressure levels for frequency-modulated (warble) tones in the sound field. J Speech Hear Disord, 1979; 44: 37-54

17. Gatehouse S, Browning GG: The output characteristics of an implanted bone conduction prosthesis. Clin Otolaryngol Allied Sci, 1990; 15: 503-13

18. Ohno T, Kajiya T: Performance of the middle ear implants. Adv Audiol, 1998; 4: 85-96

19. Dillon H, Storey L: The National Acoustic Laboratories' procedure for selecting the saturation sound pressure level of hearing aids: theoretical derivation. Ear Hear, 1998; 19: 255-66 